\title{
Transcriptomics Evaluation of Hexavalent Chromium Toxicity in Human Dermal Fibroblasts
}

\section{Rajendran Sellamuthu ${ }^{1}$, Christina Umbright ${ }^{1}$, Rebecca Chapman ${ }^{2}$, Stephen Leonard ${ }^{2}$, Shengqiao Li ${ }^{3}$, Michael Kashon ${ }^{3}$ and Pius Joseph ${ }^{1 *}$}

${ }^{1}$ Toxicology and Molecular Biology Branch, Health Effects Laboratory Division, National Institute for Occupational Safety and Health (NIOSH), Morgantown, WV ${ }^{2}$ Pathology and Physiology Research Branch, Health Effects Laboratory Division, National Institute for Occupational Safety and Health (NIOSH), Morgantown, WV ${ }^{3}$ Biostatistics and Epidemiology Branch, Health Effects Laboratory Division, National Institute for Occupational Safety and Health (NIOSH), Morgantown, WV

Data deposition: The microarray data has been deposited in the Gene Expression Omnibus (GEO) Database, www.ncbi.nlm.nih.gov/geo (accession number GSE16349)

Disclaimer: "The findings and conclusions in this report are those of the author(s) and do not necessarily represent the views of the National Institute for Occupational Safety and Health."

\begin{abstract}
Significant exposure to hexavalent chromium, a metal with broad toxicity potential in humans, has been reported. In order to understand the mechanisms of dermal toxicity induced by hexavalent chromium, global gene expression profiling of human dermal fibroblasts exposed to potassium dichromate was performed. Microarray analysis of the gene expression profile in the fibroblasts treated with potassium dichromate identified significant differential expression of approximately 1,200 transcripts compared with the control cells. Functional categorization of the differentially expressed genes identified the enrichment of genes involved in several cellular processes, including apoptosis and oxidative stress, in the fibroblasts exposed to hexavalent chromium. Induction of apoptosis and oxidative stress in the dermal fibroblasts in response to their exposure to chromium was independently confirmed by additional experiments. The potassium dichromate-induced cytotoxicity, apoptosis, and oxidative stress were significantly blocked by the addition of ferrous sulfate, an agent known for its ability to reduce chromium to the insoluble and therefore impermeable trivalent form, to the cell culture medium. Taken together, our data provide insights into the potential mechanisms underlying the dermal toxicity of hexavalent chromium and provide experimental support for the proposed protective role of ferrous sulfate in hexavalent chromium-induced toxicity.
\end{abstract}

Keywords: Hexavalent chromium; Dermal toxicity; Gene expression; Oxidative stress; Apoptosis

\section{Introduction}

Chromium, inspite of being recognized as an essential trace element, is known to cause toxicity under conditions of excessive human exposure. Chromium has been detected as a contaminant in the environment, in various food items, in water, and in certain industrial and consumer products. Similarly, large quantities of chromium are used in various industries resulting in significant occupational exposure among workers. The potential of chromium, especially its hexavalent form, to result in toxicity has been recognized for a long period of time. Treating cells cultured in vitro with hexavalent chromium resulted in cytotoxicity [1], genotoxicity [2], apoptosis [3], and cell transformation [4]. Similarly, administration of hexavalent chromium to experimental animals results in toxicity of the lungs [5], kidney [6], skin [7], and reproductive system [8]. Epidemiological evidence is also available to demonstrate the toxicity of hexavalent chromium in humans [9]. Chromium has been classified as a toxic and carcinogenic metal in humans [10].

Occupational exposure to hexavalent chromium resulting in toxicity and illnesses is a major health concern among workers in the U.S. and elsewhere. Even though the principal route of human exposure to chromium is through inhalation, and lung has been identified as the primary target organ for its toxicity [11], significant human exposure to chromium also takes place through the skin [7]. In addition, skin is a major target organ for chromium toxicity [7,11]. For example, the widespread incidence of dermatitis noticed among construction workers is believed to be due to chromium present as a contaminant in cement [7]. The incidence of allergic contact dermatitis observed among construction workers who are occupationally exposed to cement is higher than that of the general population [12], and a good correlation has been observed between the chromium content of cement and the incidence of contact dermatitis among construction workers in several countries [13]. Inspite of such compelling evidence suggesting a definite role for hexavalent chromium in dermal toxicity, the underlying mechanism(s) responsible for its toxicity on skin are not fully understood.

Because of its ability to reduce the water soluble and highly toxic hexavalent chromium $[\mathrm{Cr}(\mathrm{VI})]$ to the insoluble and less toxic trivalent chromium [Cr(III)] [14], it is expected that the addition of ferrous sulfate $\left(\mathrm{FeSO}_{4}\right)$ to products containing $\mathrm{Cr}(\mathrm{VI})$, for example cement, may be protective against its toxicity. Support to this concept is derived from the observation that in many European countries the incidence of allergic contact dermatitis (ACD) among construction workers has diminished considerably since the addition of $\mathrm{FeSO}_{4}$ to cement has been practiced [9]. However, a definite role for $\mathrm{FeSO}_{4}$ in protecting against $\mathrm{Cr}(\mathrm{VI})$-induced $\mathrm{ACD}$ has been disputed. Accordingly, better industrial hygiene practices and the more frequent use of improved personal protective devices have been attributed to be responsible

*Corresponding author: Pius Joseph, MS 3014, Molecular Carcinogenesis Laboratory, National Institute for Occupational Safety and Health (NIOSH), 1095 Willowdale Road, Morgantown, WV 26505, Tel: (304)285-6240; Fax: (304)2855708; E-mail: pjoseph1@cdc.gov

Received Janurary 05, 2011; Accepted February 24, 2011; Published February 26, 2011

Citation: Sellamuthu R, Umbright C, Chapman R, Leonard S, Li S, et al. (2011) Transcriptomics Evaluation of Hexavalent Chromium Toxicity in Human Dermal Fibroblasts. J Carcinogene Mutagene 2:116. doi:10.4172/2157-2518.1000116

Copyright: (C) 2011 Sellamuthu R, et al. This is an open-access article distributed under the terms of the Creative Commons Attribution License, which permits unrestricted use, distribution, and reproduction in any medium, provided the original author and source are credited. 
Citation: Sellamuthu R, Umbright C, Chapman R, Leonard S, Li S, et al. (2011) Transcriptomics Evaluation of Hexavalent Chromium Toxicity in Human Dermal Fibroblasts. J Carcinogene Mutagene 2:116. doi:10.4172/2157-2518.1000116

for the decline in chromium-induced ACD noticed among cement workers. In addition, experimental evidence, derived either from in vitro cell culture or in vivo animal models, supporting a definite role for $\mathrm{FeSO} 4$ in $\mathrm{Cr}(\mathrm{VI})$-induced ACD or any other type of toxicity is lacking. For example, no statistically significant difference in chromium content was noticed between skin samples exposed to cement with or without $\mathrm{FeSO}_{4}[15]$ questioning the proposed protective role of $\mathrm{FeSO}_{4}$ in chromium toxicity. The lack of experimental evidence supporting a definite protective role for $\mathrm{FeSO}_{4}$ in chromium toxicity may be one of the reasons for not adding $\mathrm{FeSO}_{4}$ to cement in many countries including the US.

Advances in high throughput gene expression profiling, such as microarray analysis, enable a comprehensive understanding of the effects of toxic chemicals in biological systems. In addition, gene expression profiling may provide mechanistic insights that may subsequently be employed to develop biomarkers to detect chemical toxicity as well as strategies to intervene chemical toxicity. Presently, the potential mechanism(s) of dermal toxicity induced by hexavalent chromium was investigated by analyzing the global gene expression profile in human dermal fibroblasts exposed to potassium dichromate. Our results demonstrated that exposure of human dermal fibroblasts to potassium dichromate resulted in toxicity, and this was associated with significant differential expression of a large number of genes including those involved in oxidative stress and apoptosis, as well as many other cellular processes. Furthermore, we have obtained data demonstrating the potential of $\mathrm{FeSO}_{4}$ to prevent/reduce the potassium dichromateinduced cytotoxicity, oxidative stress, and apoptosis in human dermal fibroblasts. The present study findings may have implications in developing strategies to prevent/reduce human dermal illnesses caused by exposure to hexavalent chromium.

\section{Materials and Methods}

\section{Cell culture and cytotoxicity studies}

Culturing of mycoplasma-free human dermal fibroblasts (Catalogue number CRL 2076, ATCC, Manassas, VA) in Iscove's modified Dulbecco's medium and determination of cytotoxicity induced by hexavalent potassium dichromate $\left[\mathrm{K}_{2} \mathrm{Cr}_{2} \mathrm{O}_{7}\right.$, abbreviated $\mathrm{Cr}(\mathrm{VI})$, Sigma Chemical Company, St Louis, $\mathrm{MO}$ ] were done exactly as described in our previous publication [1].

\section{Gene expression studies}

Microarray analysis of global gene expression profile: Exponentially growing dermal fibroblasts $\left(3 \times 10^{5}\right.$ cells) were cultured in T25 cell culture flasks. When the cells were approximately $70 \%$ confluent, $\mathrm{Cr}(\mathrm{VI})$ was added to the medium at a final concentration of $5 \mu \mathrm{M}$ (24-hour LC50 value; see Results section for details), and the cells were further cultured for 16-hours. Total RNA, free of contaminating DNA and proteins, was isolated from the cell, using the RNeasy Kit (Qiagen, Inc., Valencia, CA). The RNA was quantitated by UV-spectrophotometry, and the integrity was determined using a Bioanalyzer (Agilent Technology, Palo Alto, CA). Samples with an RNA Integrity Number (RIN) $\geq 8.0$ were used in the gene expression studies.

The global gene expression profile of the control and $\mathrm{Cr}(\mathrm{VI})$ treated fibroblasts was determined using HumanRef- 8 V2 Sentrix BeadChip array (Illumina, Inc, San Diego, CA). All microarray experiments were performed to comply with Minimal Information About a Microarray Experiment (MIAME) protocols. Biotin-labeled cRNA was generated from 375 ng RNA samples each by employing the Illumina TotalPrep RNA Amplification Kit (Ambion, Inc, Austin, TX). Chip hybridizations, washing, Cy3-streptavidin staining, and scanning of the chips were performed on the BeadStation 500 platform (Illumina, Inc, San Diego, CA) following protocols provided by the manufacturer.

Microarray data analysis: Metrics files from the bead scanner were checked to ensure that all samples fluoresced at comparable levels before samples were loaded into the Beadstudio (Framework version 3.0.19.0) Gene Expression module v.3.0.14. Housekeeping, hybridization control, stringency and negative control genes were checked for proper chip detection. BeadArray expression data were then exported with mean fluorescent intensity across like beads and bead variance estimates into flat files for subsequent analysis.

Illumina BeadArray expression data were analyzed in Bioconductor using the 'lumi' and 'limma' packages. Bioconductor is a project for the analysis and comprehension of genomic data and operates in R, a statistical computing environment. The 'lumi' Bioconductor package was specifically developed to process Illumina microarrays and covers data input, quality control, variance stabilization, normalization, and gene annotation [16]. Normalized data were then analyzed using the 'limma' package in R. In short, limma fits a linear model for each gene, generates group means of expression, calculates p-values and log fold-changes which are converted to standard fold changes. The raw $\mathrm{p}$ values were corrected for false discovery rate (FDR) using the Benjamini and Hochberg procedure [17]. Only genes with FDR $\leq 0.05$ and a fold change $\geq 1.8$ compared with the controls were considered as significantly differentially expressed and used as input for subsequent bioinformatic analysis using the Ingenuity Pathway Analysis (IPA, Ingenuity Systems, www.ingenuity.com). IPA software is designed to map the biological relationship of the uploaded genes and classify them into categories according to published literature in the database. Hierarchical clustering of all the genes detected following hybridization of the chips was done by Euclidean distance metric/uncentered Pearson correlation method (http://www.cs.umd.edu/hcil/multi-cluster/).

Real-time PCR confirmation of microarray data: A total of twenty nine genes that were differentially expressed in response to $\mathrm{Cr}(\mathrm{VI})$ exposure in the fibroblasts were randomly selected for quantitative real-time PCR (QRT-PCR) analysis to confirm the microarray data. Nucleotide sequences of the primers employed to PCR amplify the selected genes are presented in Supplemental Table 1. The PCR amplification, detection of the PCR-amplified gene products, and their quantitations were performed with the 7500HT Fast Real Time PCR machine and SYBR Green PCR Kit (Applied Biosystems, Foster City, CA). The expression levels of the genes were normalized to that of the housekeeping gene - beta-2-microglobulin (B-2-M), and the fold changes in expression compared with the controls were calculated using the formula $2^{\wedge}\left(-\left(\Delta \mathrm{Ct}\right.\right.$ t target $\left.-\Delta \mathrm{Ct} \_\mathrm{B}-2-\mathrm{M}\right)$.

Apoptosis determination : Human dermal fibroblasts $\left(2 \times 10^{5}\right.$ cells/ well) were cultured on sterile cover slips which were placed in 6 well cell culture plates and treated with $\mathrm{Cr}(\mathrm{VI})(5 \mu \mathrm{M}$ final concentration) for $16 \mathrm{hrs}$. After the exposure period, cells were washed in PBS, fixed with acetone, and stained with terminal transferase-mediated dUTP nick end-labeling (TUNEL) reagent (Promega Corporation, Madison, WI) and DAPI for detection of apoptotic and total nuclei, respectively. Apoptotic cells were detected under an Olympus AX70 fluorescence microscope using a standard fluorescein filter. The number of apoptotic nuclei (TUNEL-positive) was expressed as a percentage of total nuclei (DAPI-positive) per field. Relevant positive (cells pretreated with $6 \mathrm{U}$ $\mathrm{DNase} / \mathrm{ml}$ ) and negative (without $\mathrm{TdT}$ ) controls were also included in the experiment.

Detection of oxidants in $\mathrm{Cr}(\mathrm{VI})$ exposed fibroblasts: The dye 5-(and-6)-chloromethyl-2',7'-dichlorodihydrofluorescein diacetate, 
Citation: Sellamuthu R, Umbright C, Chapman R, Leonard S, Li S, et al. (2011) Transcriptomics Evaluation of Hexavalent Chromium Toxicity in Human Dermal Fibroblasts. J Carcinogene Mutagene 2:116. doi:10.4172/2157-2518.1000116

acetyl ester (CM-H2DCFDA) purchased from Invitrogen Corporation (Carlsbad, CA) was used to determine the production of oxidizing species in the dermal fibroblasts exposed to $\mathrm{Cr}(\mathrm{VI})$. The yield of the fluorescent 2',7'-dichlorofluorescein (DCF), the oxidation product of $\mathrm{DCFH}$, is considered as a reflection of the overall production of $\mathrm{Cr}(\mathrm{VI})$ reductive intermediates $[18,19]$ and reactive oxygen species such as hydrogen peroxide $\left(\mathrm{H}_{2} \mathrm{O}_{2}\right)$ [20] and hydroxyl radical $(\mathrm{OH})$ [21]. Cells were plated onto circular glass cover slips in 24-well plates and treated with $5 \mu \mathrm{M} \mathrm{Cr}(\mathrm{VI})$ for 1.5-hours. Staining of the control and treated cells with the dye and detection of the stained cells by confocal microscopy was done exactly as described in our previous study [22]. Images were recorded in pseudocolor, where low intensity sites appear blue and increasingly high intensity areas are displayed as green, yellow, red, or white with a pixel intensity of 0-255.

Role of $\mathrm{FeSO}_{4}$ in $\mathrm{Cr}(\mathrm{VI})$ toxicity: In an effort to obtain experimental data to support the proposed protective role of $\mathrm{FeSO} 4$ against $\mathrm{Cr}(\mathrm{VI})$ toxicity, studies were conducted to determine cytotoxicity, apoptosis and oxidative stress in the dermal fibroblasts exposed to $\mathrm{Cr}(\mathrm{VI})$ and FeSO4. Exponentially growing dermal fibroblasts were treated with $\mathrm{Cr}(\mathrm{VI})$ in the presence or absence of $\mathrm{FeSO} 4 . \mathrm{Cr}(\mathrm{VI})$ and $\mathrm{FeSO} 4$ were

\begin{tabular}{|c|c|c|c|}
\hline Gene Symbol & Control & $\mathrm{Cr}(\mathrm{VI})$ treated & Fold change \\
\hline HB2M & $21.315 \pm 0.117$ & $21.842 \pm 0.224$ & - \\
\hline IL8 & $36.665 \pm 0.321$ & $29.026 \pm 0.130^{*}$ & +292.684 \\
\hline HMOX1 & $27.397 \pm 0.136$ & $25.4 \pm .093^{*}$ & +5.862 \\
\hline GDF15 & $26.673 \pm 0.212$ & $21.153 \pm 0.215^{*}$ & +67.378 \\
\hline FOS & $33.544 \pm 0.229$ & $28.757 \pm 0.103^{*}$ & +40.544 \\
\hline RGS4 & $34.232 \pm 0.202$ & $30.691 \pm 0.206^{*}$ & +17.087 \\
\hline AXUD1 & $31.087 \pm 0.084$ & $28.287 \pm 0.075^{*}$ & +11.078 \\
\hline H3F3B & $30.331 \pm 0.189$ & $28.063 \pm 0.085^{\star}$ & +7.073 \\
\hline ANGPTL4 & $35.015 \pm 0.241$ & $32.2 \pm 0.310^{*}$ & +10.335 \\
\hline TNFRSF10D & $27.235 \pm 0.131$ & $24.544 \pm 0.234^{*}$ & +9.485 \\
\hline GADD45A & $26.291 \pm 0.105$ & $24.092 \pm 0.096^{*}$ & +6.746 \\
\hline GAS & $26.127 \pm 0.131$ & $33.384 \pm 0.124^{*}$ & -104.17 \\
\hline DDIT4 & $28.138 \pm 0.172$ & $30.887 \pm 0.247^{*}$ & -4.576 \\
\hline KIAA1199 & $24.767 \pm 0.239$ & $29.408 \pm 0.355^{\star}$ & -16.995 \\
\hline CXCL12 & $25.924 \pm 0.141$ & $30.841 \pm 0.135^{\star}$ & -20.566 \\
\hline DKK1 & $22.619 \pm 0.158$ & $26.384 \pm 0.132^{*}$ & -9.259 \\
\hline HMGCR & $30.413 \pm 0.230$ & $33.262 \pm 0.114^{*}$ & -4.905 \\
\hline KRT19 & $25.010 \pm 0.129$ & $29.197 \pm 0.222^{*}$ & -12.399 \\
\hline DHRS3 & $22.931 \pm 0.318$ & $26.164 \pm 0.267^{*}$ & -6.402 \\
\hline PTK2 & $27.950 \pm 0.268$ & $30.862 \pm 0.406^{*}$ & -5.128 \\
\hline TNS3 & $25.680 \pm 0.169$ & $30.639 \pm 0.371^{*}$ & -21.162 \\
\hline IRXL1 & $27.155 \pm 0.198$ & $31.224 \pm 0.170^{*}$ & -11.43 \\
\hline LMCD1 & $27.572 \pm 0.201$ & $31.893 \pm 0.143^{*}$ & -13.612 \\
\hline HOXA10 & $26.051 \pm 0.220$ & $28.967 \pm 0.171^{*}$ & -5.141 \\
\hline IFIT1 & $29.75 \pm 0.425$ & $35.132 \pm 0.253^{*}$ & -28.392 \\
\hline PPP1R3C & $27.317 \pm 0.298$ & $29.058 \pm 0.190^{*}$ & -2.277 \\
\hline INSIG1 & $26.285 \pm 0.293$ & $30.156 \pm 0.207^{*}$ & -9.963 \\
\hline HMGCS1 & $26.772 \pm 0.359$ & $31.674 \pm 0.167^{*}$ & -20.353 \\
\hline SERPINB1 & $27.864 \pm 0.135$ & $31.006 \pm 0.074^{*}$ & -6.012 \\
\hline PRKD1 & $31.694 \pm 0.161$ & $35.777 \pm 0.230^{*}$ & -11.317 \\
\hline
\end{tabular}

Based on the microarray data, 29 genes were selected for real time PCR analysis to confirm their differential expression in the cells treated with $\mathrm{Cr}(\mathrm{VI})$. ' + ' and '-' represent overexpression and underexpression, respectively, of the genes in the $\mathrm{Cr}(\mathrm{VI})$ treated cells compared with the control cells. Data presented is the threshold cycle (CT) derived from real time PCR analysis and are mean \pm S.E. of four independent experiments. The fold change in expression of the individual genes in the $\mathrm{Cr}(\mathrm{VI})$ treated cells compared with the control was calculated as described in the text. Statistical analysis of the data was done by Student's t test and a $p$ value $\leq 0.05$ was considered as statistically significant $\left(^{*}\right)$.

Table 1: Real Time PCR Confirmation of Differential Gene Expression in Human Dermal Fibroblasts Exposed to $5 \mu \mathrm{M} \mathrm{Cr}(\mathrm{VI})$.

\begin{tabular}{|l|l|l|}
\hline Category & p-value* & $\begin{array}{l}\text { Number } \\
\text { of } \\
\text { genes\# }\end{array}$ \\
\hline Cell Death & $4.74 \mathrm{E}-09-1.82 \mathrm{E}-01$ & 206 \\
\hline Cellular Growth and Proliferation & $1.38 \mathrm{E}-06-1.82 \mathrm{E}-01$ & 221 \\
\hline Cell Cycle & $2.46 \mathrm{E}-03-1.82 \mathrm{E}-01$ & 90 \\
\hline DNA Replication, Recombination, and Repair & $4.28 \mathrm{E}-03-1.82 \mathrm{E}-01$ & 55 \\
\hline Cellular Development & $5.94 \mathrm{E}-03-1.82 \mathrm{E}-01$ & 144 \\
\hline Gene Expression & $9.22 \mathrm{E}-03-1.82 \mathrm{E}-01$ & 142 \\
\hline Cell-To-Cell Signaling and Interaction & $2.71 \mathrm{E}-02-1.82 \mathrm{E}-01$ & 39 \\
\hline Cell Morphology & $3.26 \mathrm{E}-02-1.82 \mathrm{E}-01$ & 95 \\
\hline Cellular Movement & $3.26 \mathrm{E}-02-1.82 \mathrm{E}-01$ & 63 \\
\hline Cellular Assembly and Organization & $5.56 \mathrm{E}-02-1.82 \mathrm{E}-01$ & 24 \\
\hline Carbohydrate Metabolism & $8.21 \mathrm{E}-02-1.76 \mathrm{E}-01$ & 21 \\
\hline Lipid Metabolism & $8.21 \mathrm{E}-02-1.68 \mathrm{E}-01$ & 32 \\
\hline Molecular Transport & $8.21 \mathrm{E}-02-1.76 \mathrm{E}-01$ & 33 \\
\hline Nuclic Acid Metabolism & $8.21 \mathrm{E}-02-1.82 \mathrm{E}-01$ & 4 \\
\hline Small Molecule Biochemistry & $8.21 \mathrm{E}-02-1.82 \mathrm{E}-01$ & 48 \\
\hline Antigen Presentation & $9.25 \mathrm{E}-02-1.76 \mathrm{E}-01$ & 29 \\
\hline Cellular Function and Maintenance & $9.47 \mathrm{E}-02-1.76 \mathrm{E}-01$ & 21 \\
\hline Cell Signaling & $1.14 \mathrm{E}-01-1.76 \mathrm{E}-01$ & 44 \\
\hline Amino Acid Metabolism & $1.35 \mathrm{E}-01-1.76 \mathrm{E}-01$ & 4 \\
\hline Vitamin and Mineral Metabolism & $1.35 \mathrm{E}-01-1.35 \mathrm{E}-01$ & 3 \\
\hline Protein Synthesis & $1.82 \mathrm{E}-01-1.82 \mathrm{E}-01$ & 27 \\
\hline The -01 & & \\
\hline
\end{tabular}

*The ' $p$-value' was calculated using the right-tailed Fisher Exact Test and corrected for false discovery rate by the Benjamini-Hochberg method. Only those categories with a $\mathrm{p}$ value $<0.05$ are considered significant and therefore are presented. \#The 'number of genes' represents the number of differentially expressed genes belonging to the specific IPA category in the $\mathrm{Cr}(\mathrm{VI})$ treated cells.

Table 2: IPA Classification of the Differentially Expressed Genes in the $\mathrm{Cr}(\mathrm{VI})$ treated Dermal Fibroblasts into Cellular and Molecular Functions Categories.

used at final concentrations of $5 \mu \mathrm{M}$ and $40 \mu \mathrm{M}$, respectively. At the end of the exposure period, cytotoxicity (MTT assay), apoptosis (TUNEL assay), and oxidative stress (confocal microscopy) were determined as described in respective sections above.

\section{Results}

\section{$\mathrm{Cr}(\mathrm{VI})$ cytotoxicity in human dermal fibroblasts}

Exposure of dermal fibroblasts to $\mathrm{Cr}(\mathrm{VI})$ resulted in concentrationdependent cytotoxicity and cell death and a 24-hour LC50 value of $5 \mu \mathrm{M}$ was calculated from the concentration-response curve. These results were essentially similar to those of our previous publication [1] and are, therefore, not presented here. Exposure of fibroblasts to $5 \mu \mathrm{M} \mathrm{Cr}(\mathrm{VI})$ for 16-hours (the time interval employed in the case of gene expression experiment) resulted in $<30 \%$ cell death (data not presented).

\section{Differential gene expression profile in fibroblasts treated with Cr(VI)}

Out of the 22185 transcripts that are represented on the Illumina Human Ref 8 microarray, the expressions of 10917 transcripts were detected in the $\mathrm{Cr}(\mathrm{VI})$ treated cells. Out of the 10917 transcripts that were detected on the microarray, 1153 genes were significantly differentially expressed ( $\mathrm{p} \leq 0.05$ adjusted for FDR by Benjamini and Hochberg correction and $\geq 1.8$-fold change in expression) in the $\mathrm{Cr}(\mathrm{VI})$-treated cells compared with the control (Supplemental Table 2). The 1153 differentially expressed genes consisted of 468 and 685 genes whose expressions were up- and down-regulated, respectively.

Results of the QRT-PCR analysis further confirmed the microarray data - expressions of all 29 genes selected for the PCR analysis were found significantly different in the $\mathrm{Cr}(\mathrm{VI})$-treated cells compared with the control cells (Table 1). 
Citation: Sellamuthu R, Umbright C, Chapman R, Leonard S, Li S, et al. (2011) Transcriptomics Evaluation of Hexavalent Chromium Toxicity in Human Dermal Fibroblasts. J Carcinogene Mutagene 2:116. doi:10.4172/2157-2518.1000116

Page 4 of 8

The functional annotation of the differentially expressed genes by IPA identified several cellular functions, pathways, and networks that were significantly enriched in the fibroblasts due to their exposure to $\mathrm{Cr}$ (VI) (Table 2). More than 200 genes that were differentially expressed in the $\mathrm{Cr}(\mathrm{VI})$-treated cells were found to be related to cell death. A further categorization of the differentially expressed genes involved in cell death function identified the differential expression of 170 genes that were involved in apoptosis (Table 3). Other major functional groups of the differentially expressed genes were cell-to-cell signaling and interaction (39 genes), cellular assembly and organization (24 genes), cellular growth and proliferation (221 genes), cellular development (144 genes), cell morphology (95 genes), cellular movement (63 genes), cell cycle (90 genes), and cellular function and maintenance (21 genes) (Table 2). IPA classification of the differentially expressed genes into diseases and disorders categories identified the differential expression of 302 and 30 genes involved in cancer and dermatological diseases and conditions, respectively (Table 4). In addition, several genes involved in diseases of other organs/tissues and systems were also found differentially expressed in the $\mathrm{Cr}(\mathrm{VI})$-treated dermal fibroblasts.

\begin{tabular}{|l|l|l|}
\hline Category & p-value* & Number of Genes\# \\
\hline Apoptosis & $4.74 \mathrm{E}-09-1.82 \mathrm{E}-01$ & 170 \\
\hline Cell Death & $1.53 \mathrm{E}-08-1.81 \mathrm{E}-01$ & 188 \\
\hline Survival & $4.71 \mathrm{E}-02-1.35 \mathrm{E}-01$ & 61 \\
\hline Cell Viability & $3.07 \mathrm{E}-02-1.82 \mathrm{E}-01$ & 26 \\
\hline Anoikis & $8.50 \mathrm{E}-02-1.82 \mathrm{E}-01$ & 10 \\
\hline
\end{tabular}

*The 'p-value' was calculated using the right-tailed Fisher Exact Test and corrected for false discovery rate by the Benjamini-Hochberg method. Only those categories with a $p$ value $\leq 0.05$ are considered significant and therefore are presented. \#The 'number of genes' represents the number of differentially expressed genes belonging to the specific IPA category in the $\mathrm{Cr}(\mathrm{VI})$ treated cells.

Table 3: IPA Classification of the Differentially Expressed Genes in the $\mathrm{Cr}(\mathrm{VI})$ treated Dermal Fibroblasts into Categories Related to Cell Death Function.

\begin{tabular}{|l|l|l|}
\hline Category & p-value* & $\begin{array}{l}\text { Number of } \\
\text { Genes\# }\end{array}$ \\
\hline Cancer & $4.74 \mathrm{E}-09-1.82 \mathrm{E}-01$ & 302 \\
\hline Gastrointestinal Disease & $1.28 \mathrm{E}-05-1.82 \mathrm{E}-01$ & 95 \\
\hline Reproductive System Disease & $4.73 \mathrm{E}-05-1.82 \mathrm{E}-01$ & 163 \\
\hline Genetic Disorder & $2.46 \mathrm{E}-02-1.46 \mathrm{E}-01$ & 96 \\
\hline Infectious Disease & $1.23 \mathrm{E}-02-1.82 \mathrm{E}-01$ & 6 \\
\hline Inflammatory Disease & $1.23 \mathrm{E}-02-1.76 \mathrm{E}-01$ & 52 \\
\hline Neurological Disease & $1.23 \mathrm{E}-02-1.82 \mathrm{E}-01$ & 46 \\
\hline Skeletal and Muscular Disorders & $1.53 \mathrm{E}-02-1.76 \mathrm{E}-01$ & 78 \\
\hline Dermatological Diseases and Conditions & $1.88 \mathrm{E}-02-1.82 \mathrm{E}-01$ & 30 \\
\hline Connective Tissue Disorders & $3.06 \mathrm{E}-02-1.82 \mathrm{E}-01$ & 84 \\
\hline Endocrine System Disorders & $3.26 \mathrm{E}-02-1.82 \mathrm{E}-01$ & 32 \\
\hline Inflammatory Response & $3.26 \mathrm{E}-02-1.76 \mathrm{E}-01$ & 29 \\
\hline Organismal Injury and Abnormalities & $3.84 \mathrm{E}-02-1.35 \mathrm{E}-01$ & 9 \\
\hline Hematological Disease & $3.88 \mathrm{E}-02-1.81 \mathrm{E}-01$ & 95 \\
\hline Renal and Urological Disease & $4.71 \mathrm{E}-02-1.82 \mathrm{E}-01$ & 26 \\
\hline Respiratory Disease & $4.81 \mathrm{E}-02-1.46 \mathrm{E}-01$ & 51 \\
\hline Immunological Disease & $6.32 \mathrm{E}-02-1.82 \mathrm{E}-01$ & 49 \\
\hline Hepatic System Disease & $1.12 \mathrm{E}-01-1.12 \mathrm{E}-01$ & 4 \\
\hline Developmental Disorder & $1.20 \mathrm{E}-01-1.76 \mathrm{E}-01$ & 10 \\
\hline Cardiovascular Disease & $1.20 \mathrm{E}-01-1.82 \mathrm{E}-01$ & 37 \\
\hline Metabolic Disease & $1.50 \mathrm{E}-01-1.82 \mathrm{E}-01$ & 12 \\
\hline Antimicrobial Response & $1.76 \mathrm{E}-01-1.76 \mathrm{E}-01$ & 3 \\
\hline The 'p-vale'was calculat & & \\
\hline
\end{tabular}

*The ' $p$-value' was calculated using the right-tailed Fisher Exact Test and corrected for false discovery rate by the Benjamini-Hochberg method. Only those categories with a $p$ value $\leq 0.05$ are considered significant and therefore are presented. \#The 'number of genes' represents the number of differentially expressed genes belonging to the specific IPA category in the $\mathrm{Cr}(\mathrm{VI})$ treated cells.

Table 4: IPA Classification of the Differentially Expressed Genes in the $\mathrm{Cr}(\mathrm{VI})$ treated Dermal Fibroblasts into Diseases and Disorders Categories.

\begin{tabular}{|l|l|l|}
\hline Category & p-value* & $\begin{array}{l}\text { Number of } \\
\text { Genes\# }\end{array}$ \\
\hline Cholesterol Biosynthesis & $2.14 \mathrm{E}-04$ & 7 \\
\hline Oxidative stress response mediated by NRF2 & $1.50 \mathrm{E}-02$ & 20 \\
\hline VDR/RXR activation & $1.50 \mathrm{E}-02$ & 11 \\
\hline p53 Signaling & $3.38 \mathrm{E}-02$ & 11 \\
\hline $\begin{array}{l}\text { Hormone Receptor Regulated Cholesterol } \\
\text { Metabolism }\end{array}$ & $3.90 \mathrm{E}-02$ & 3 \\
\hline Oxidative Stress & $4.49 \mathrm{E}-01$ & 5 \\
\hline
\end{tabular}

*The 'p-value' was calculated using the right-tailed Fisher Exact Test and corrected for false discovery rate by the Benjamini-Hochberg method. Only those categories with a $\mathrm{p}$ value $\leq 0.05$ are considered significant and therefore are presented.

\#The 'number of genes' represents the number of differentially expressed genes belonging to the specific IPA category in the $\mathrm{Cr}(\mathrm{VI})$ treated cells.

Table 5: IPA Classification of the Differentially Expressed Genes in the $\mathrm{Cr}(\mathrm{VI})$ treated Dermal Fibroblasts into Toxicology Categories.

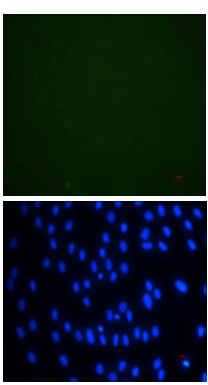

Control

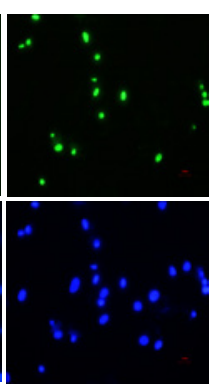

$\operatorname{Cr}(\mathbf{V I})$

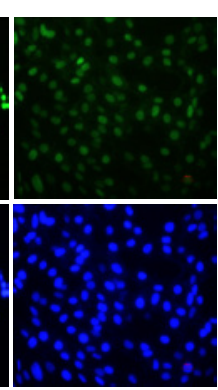

Dnase $\checkmark$ TUNEL

\section{DAPI}

Figure 1: $\mathrm{Cr}(\mathrm{VI})$-induced apoptosis in human dermal fibroblasts. Human dermal fibroblasts were treated with $5 \mu \mathrm{M} \mathrm{Cr}(\mathrm{VI})$ for 16 and 24-hours and the cells were stained with TUNEL reagent and DAPI to detect apoptotic and total nuclei, respectively. Cells treated with DNase were used as positive control for apoptosis. The experiment was repeated four times, and the results of a representative 24-hour experiment are presented. TUNEL positive apoptotic nuclei are presented in the upper row, and the same cells stained with DAP showing apoptotic and non-apoptotic nuclei are presented in the lower row.

Oxidative stress was the most prominent toxicological category enriched by $\mathrm{Cr}(\mathrm{VI})$ as identified by the IPA analysis of the differentially expressed genes (Table 5). Out of the 25 oxidative stress related genes that were differentially expressed in the $\mathrm{Cr}(\mathrm{VI})$-treated cells, 20 genes belonged to the IPA category of oxidative stress response mediated by Nrf2.

\section{$\mathrm{Cr}(\mathrm{VI})$-induced apoptosis in dermal fibroblasts}

Exposure of the human dermal fibroblasts to $5 \mu \mathrm{M} \mathrm{Cr}(\mathrm{VI})$ resulted in induction of apoptosis as evidenced from the number of TUNELpositive apoptotic nuclei in the treated cells compared with the control (Figure 1)

\section{$\mathrm{Cr}(\mathrm{VI})$-induced oxidative stress in dermal fibroblasts}

Exposure of dermal fibroblasts to $\mathrm{Cr}(\mathrm{VI})$ resulted in oxidative stress as evidenced from the results of the confocal microscopy analysis (Figure 2). Compared with the control cells, the fibroblasts treated with $\mathrm{Cr}(\mathrm{VI})$ exhibited a significantly elevated cellular level of oxidants capable of inducing oxidative stress .

Inhibition of $\mathrm{Cr}(\mathrm{VI})$-induced cytotoxicity, apoptosis, and oxidative stress by $\mathrm{FeSO}_{4}$

Addition of $\mathrm{FeSO}_{4}$ to the cell culture medium significantly blocked $\mathrm{Cr}(\mathrm{VI})$ - induced cytotoxicity (Figure $3 \mathrm{~A}$ ), apoptosis (Figure $3 \mathrm{~B}$ ), and reductive metabolism of $\mathrm{Cr}(\mathrm{VI})$ resulting in the generation of reactive 
Citation: Sellamuthu R, Umbright C, Chapman R, Leonard S, Li S, et al. (2011) Transcriptomics Evaluation of Hexavalent Chromium Toxicity in Human Dermal Fibroblasts. J Carcinogene Mutagene 2:116. doi:10.4172/2157-2518.1000116

oxidant metabolites and toxic reactive oxygen species capable of inducing oxidative stress (Figure 2).

\section{Discussion}

Recent developments in transcriptomics have facilitated a better understanding of the potential for chemicals to cause toxicity as well as the molecular mechanisms underlying their toxicity. In the present study, exposure of human dermal fibroblasts to $\mathrm{Cr}(\mathrm{VI})$ resulted in toxicity as well as significant differential expression of approximately 1,200 genes as demonstrated by the microarray data. Functional analysis of the differentially expressed genes facilitated a better understanding of the mechanisms potentially underlying the dermal toxicity of $\mathrm{Cr}(\mathrm{VI})$ through identification of multiple cellular processes/functions/ pathways/networks that are affected as a consequence of exposure to $\mathrm{Cr}(\mathrm{VI})$.

The present study is a follow-up of one of our previous publications[1] in which we employed a microarray that contained 263 genes, whose expression are indicative of stress and toxicity, to determine the mechanisms underlying $\mathrm{Cr}(\mathrm{VI})$-induced dermal toxicity. The microarray employed in the present study contained more than 22,000 genes involved in a variety of cellular functions and, therefore, is expected to provide a broader understanding of the dermal

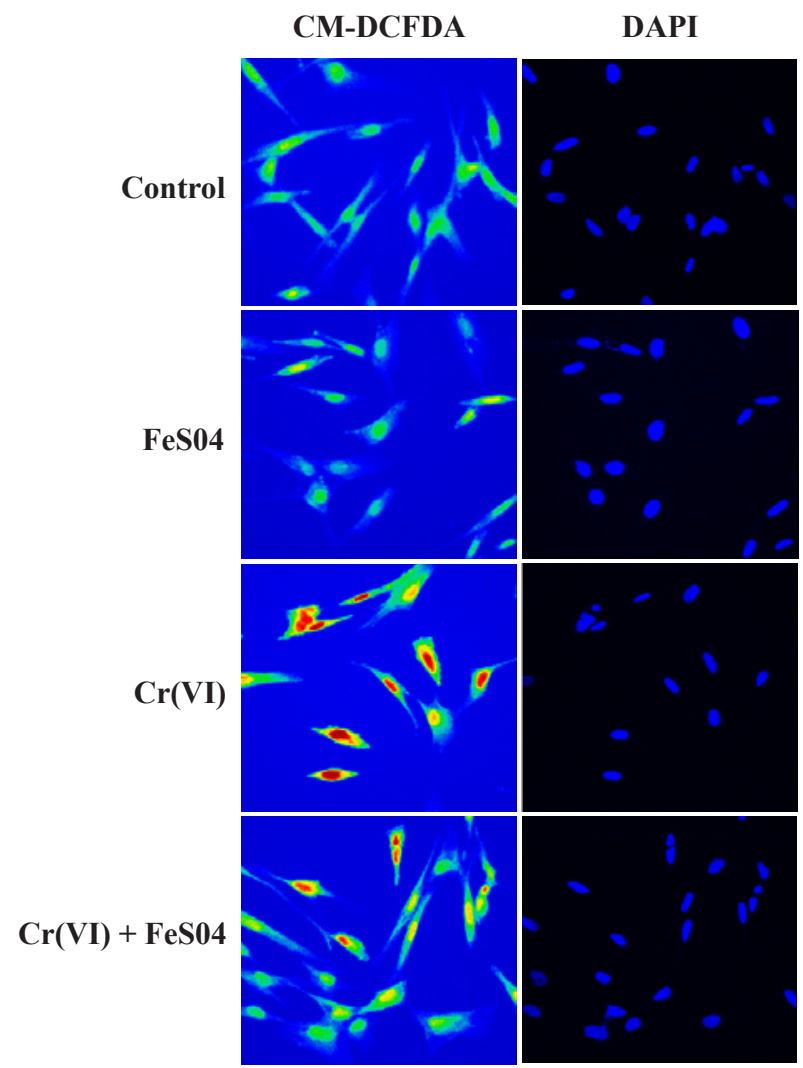

Figure 2: Detection of reactive oxygen species (ROS) in human dermal fibroblasts exposed to $\mathrm{Cr}(\mathrm{VI})$ with or without $\mathrm{FeSO}_{4}$. Exponentially growing human dermal fibroblasts were exposed to $5 \mu \mathrm{M} \mathrm{Cr}(\mathrm{VI})$ with or without $40 \mu \mathrm{M} \mathrm{FeSO}$ as described in the Materials and methods section The cells were stained with the fluorescent dye 5-(and-6)-chloromethyl-2', 7'dichlorodihydrofluorescein diacetate, acetyl ester (CM- $\mathrm{H}_{2}$ DCFDA), capable of detecting $\mathrm{Cr}(\mathrm{VI})$ reductive metabolites and reactive oxygen species and the nuclear dye, DAPI. The stained cells were detected by confocal microscopy and a representative field is presented. The various colors in the photographs represent the cellular level of ROS in decreasing order as follows: red > yellow $>$ green $>$ blue.
A
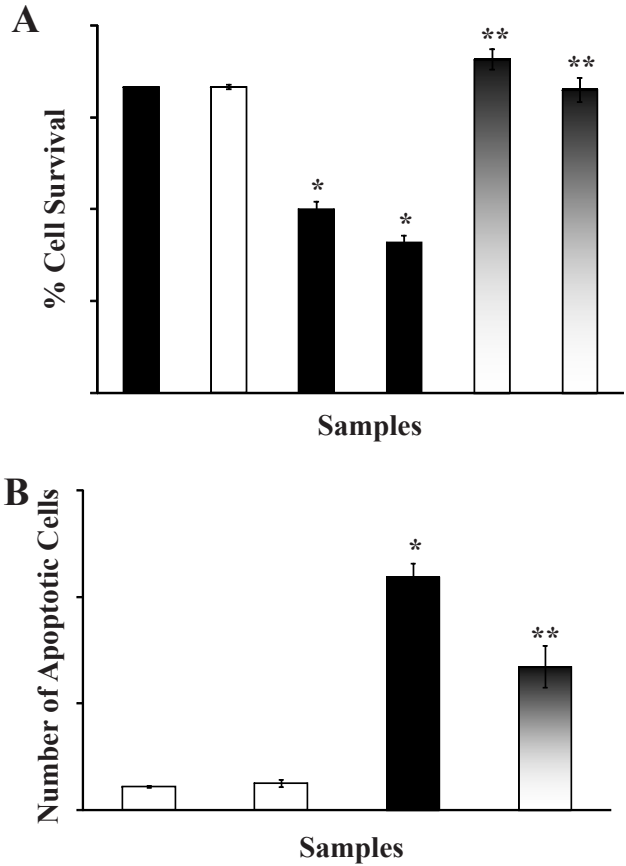

*Statistically significant $(p<0.05)$ compared with the untreated control cells. ${ }^{*}$ Statistically significant $(\mathrm{p}<0.05)$ compared with the corresponding $\mathrm{Cr}(\mathrm{VI})$ treated cells.

Figure 3: FeSO -mediated blocking of cytotoxicity (A) and apoptosis (B) in human dermal fibroblasts treated with $\mathrm{Cr}(\mathrm{VI})$. Fibroblasts were treated with $\mathrm{Cr}(\mathrm{VI})$ and $\mathrm{FeSO}_{4}$ at the indicated concentrations and cytotoxicity and apoptosis were determined by MTT assay and TUNEL assay, respectively, as described in the text. The experiment was repeated four times and the data is presented as mean \pm S.E. For TUNEL assay, four independent microscopic fields, each consisting of 30-50 cells, were counted per experiment and the data is used. Statistical analysis was done by Tukey's Honest Significant Difference (HSD) procedure

toxicity potential of $\mathrm{Cr}(\mathrm{VI})$ as well as further insight into the possible mechanisms underlying the toxicity.

Exposure of dermal fibroblasts to $\mathrm{Cr}(\mathrm{VI})$ resulted in toxicity and this was associated with significant differential expression of approximately 1,200 genes in the treated cells compared with the controls. The cytotoxicity data obtained in the present investigation is in agreement with our previous report [1] and further supports the dermal toxicity potential of $\mathrm{Cr}(\mathrm{VI})$ [7]. Many of the genes that were differentially expressed in our previous study [1] were also found differentially expressed in the current study. However, quantitative differences in the expression of those genes were noticed between the two studies. This may be attributed to the differences in the microarray platforms employed and/or the duration of $\mathrm{Cr}(\mathrm{VI})$ exposure (16-hours in the present study vs 2,6 , and 24-hours in the previous study). Bioinformatic analysis of the differentially expressed genes in the $\mathrm{Cr}(\mathrm{VI})$ treated dermal fibroblasts suggested the potential of $\mathrm{Cr}(\mathrm{VI})$ to cause cancer, inflammatory, immunological, endocrinological, metabolic, and genetic diseases in the skin. In addition, classification of the differentially expressed genes in the $\mathrm{Cr}(\mathrm{VI})$ exposed cells into various biological categories provided insight regarding the potential mechanisms underlying the $\mathrm{Cr}(\mathrm{VI})$-induced dermal toxicity. As presented in Table 2, a large number of genes involved in vital molecular and cellular functions such as development, growth, differentiation, proliferation, signaling, metabolism, movement, transport, cell cycle, etc., were found differentially expressed in the $\mathrm{Cr}(\mathrm{VI})$-treated cells compared to the untreated control cells. It is possible that exposure 
Citation: Sellamuthu R, Umbright C, Chapman R, Leonard S, Li S, et al. (2011) Transcriptomics Evaluation of Hexavalent Chromium Toxicity in Human Dermal Fibroblasts. J Carcinogene Mutagene 2:116. doi:10.4172/2157-2518.1000116

of dermal fibroblasts to a toxic concentration of $\mathrm{Cr}(\mathrm{VI})$ resulted in the abnormal expression of several genes thereby interfering with the biological and molecular functions mediated by these genes so as to result in cytotoxicity and cell death. Alternatively, some of the gene expression changes observed may represent adaptive responses of the cells to combat $\mathrm{Cr}(\mathrm{VI})$ toxicity or effects secondary to the toxicity of the chemical. Many of the cellular functions which were interrupted by $\mathrm{Cr}(\mathrm{VI})$ exposure in the dermal fibroblasts were also affected in human peripheral blood mononuclear cells [23] and human pulmonary epithelial cell line A549 [24] exposed to Cr(VI) suggesting the possible involvement of common mechanisms in the toxicity of $\mathrm{Cr}(\mathrm{VI})$ in cell lines derived from different target organs/tissues.

Reactive oxygen species (ROS) responsible for the induction of oxidative stress play a central role in the toxicity of transition metals including $\mathrm{Cr}(\mathrm{VI})$. Upon entering the cells, $\mathrm{Cr}(\mathrm{VI})$ is reduced both enzymatically $[25,26]$ and non-enzymatically [14] to intermediates of lower valences; this is often accompanied by the generation of ROS resulting in oxidative stress and toxicity. Unless efficiently detoxified and immediately removed, the ROS generated can interact with intracellular targets to result in toxicity [14]. The microarray findings, in conjunction with those of the confocal microscopy study, support the existence of pro-oxidant conditions in the $\mathrm{Cr}(\mathrm{VI})$ treated dermal fibroblasts capable of resulting in toxicity. Superoxide dismutase (SOD), responsible for the dismutation of superoxide anion to result in the generation of $\mathrm{H}_{2} \mathrm{O}_{2}$, was found significantly overexpressed in the $\mathrm{Cr}(\mathrm{VI})$-treated cells. The $\mathrm{H}_{2} \mathrm{O}_{2}$ thus generated, if not detoxified immediately, may result in its cellular accumulation resulting in toxicity [27]. Catalase plays a major role in detoxifying $\mathrm{H}_{2} \mathrm{O}_{2}$ [28], and in the $\mathrm{Cr}(\mathrm{VI})$-treated cells the expression of catalase gene was significantly down-regulated compared with the control cells. The overexpression of SOD along with the downregulation of catalase gene expression should have facilitated increased generation and accumulation of $\mathrm{H}_{2} \mathrm{O}_{2}$ in the $\mathrm{Cr}(\mathrm{VI})$ treated cells. The $\mathrm{H}_{2} \mathrm{O}_{2}$ accumulated in the cells can interact with cellular targets to result in toxicity. The confocal microscopy results demonstrating the elevated cellular level of oxidants such as the reductive intermediates of $\mathrm{Cr}(\mathrm{VI})$ and reactive oxygen species in the $\mathrm{Cr}(\mathrm{VI})$ treated cells further supported the microarray findings. Several stress response genes including HO-1 [29], members of the heat shock proteins [30], metallothionein [31], growth differentiation factor 15 [32], etc, were found significantly overexpressed in the $\mathrm{Cr}(\mathrm{VI})$ treated fibroblasts, further supporting the induction of cellular stress in response to $\mathrm{Cr}(\mathrm{VI})$ exposure .

Cells, in general, defend against oxidative stress and the resulting toxicity induced by ROS by activating the cellular defense machinery collectively referred to as oxidative stress response. The transcription factor - nuclear factor-E2 related factor (Nrf2), is a key member of the cellular antioxidant response system and facilitates the detoxification of ROS by transcriptional activation of one or several phase II detoxifying genes and stress-inducible genes [33]. The activation of the Nrf2 signaling pathway in response to exposure of mouse hepalc1c7 cells to $\mathrm{Cr}(\mathrm{VI})$ has been recently reported [34] as a protective mechanism against chromium-induced apoptosis. Similarly, a definite role for the Nrf2-mediated antioxidant response system in protecting hepatocytes against chromium-induced stress and toxicity has been implicated based on the results of studies conducted in rats [35]. The reported protective role of Nrf2 against oxidative stress is presumably due to the antioxidant response element (ARE)-mediated induction of expression of phase II detoxifying genes and stress-inducible genes [33]. Expression of several genes encoding cytoprotective detoxification enzymes is coordinately regulated by Nrf2- a redox sensitive transcription factor, through its interaction with the antioxidant responsive element (ARE) present in the 5' flanking region of these genes [36]. The activation of genes involved in the oxidative stress response mediated by Nrf2 (Table 5 ) in the fibroblasts in response to $\mathrm{Cr}(\mathrm{VI})$ exposure, therefore, can be considered as an adaptive response of the cells to detoxify ROS to result in protection against $\mathrm{Cr}(\mathrm{VI})$ toxicity.

Apoptosis is a physiological adaptation whereby cells undergo programmed death in response to unrepairable DNA damage induced by toxic chemicals. The structural and functional damage to DNA observed in cells exposed to $\mathrm{Cr}(\mathrm{VI})$ is attributed both to the reactive chromium intermediates and the ROS generated during the intracellular reduction of $\mathrm{Cr}(\mathrm{VI})$ [37]. It is well established that $\mathrm{Cr}(\mathrm{VI})$ induces generation of ROS and concomitant DNA damage leading to apoptosis in cells [38]. The Gadd45a gene, whose expression is considered as a marker for cellular response to DNA damage [39], was found significantly overexpressed in the fibroblasts treated with $\mathrm{Cr}(\mathrm{VI})$. Gadd45a interacts with proliferating cell nuclear antigen (PCNA), a nuclear protein that plays a central role in DNA damage repair [40]. The significant overexpression of both Gadd45a and PCNA in the Cr(VI) treated cells may, therefore, be considered an adaptive response of the cells to repair the DNA damage induced by $\mathrm{Cr}(\mathrm{VI})$ metabolites and/ or the ROS generated. Functional categorization of the differentially expressed genes in the $\mathrm{Cr}(\mathrm{VI})$ treated cells identified the differential expression of several genes involved in apoptosis (Table 3 ) potentially resulting in the induction of apoptosis as a likely response of the fibroblasts to $\mathrm{Cr}(\mathrm{VI})$ exposure. Pro-apoptotic genes such as phorbol12-myristate-13-acetate-induced protein 1 (PMAIP1) [41], B-cell CLL/ lymphoma 6 (BCL6) [42], tumor protein $\mathrm{p} 53$ inducible nuclear protein 1 (TP53INP1) [43], tumor necrosis factor receptor superfamily, member $10 \mathrm{~A}$ and B (TNFRS10A and B) [44], BCL2/adenovirus E1B 19kDa interacting protein 3 (BNIP3) [45], death effector domain containing 2 (DEDD2) [46], etc, were overexpressed while antiapoptotic genes such as cyclin dependent kinase 9 (CDK9) [47], protein kinase C alpha (PKCA) [48], fas apoptotic inhibitory molecule (FAIM) [49], kruppellike factor 2 (KLF2) [50], etc, were repressed in the $\mathrm{Cr}(\mathrm{VI})$ exposed cells facilitating apoptosis induction. The results of TUNEL assay further confirmed the microarray findings and demonstrated the induction of apoptosis as a cellular response of the fibroblasts to $\mathrm{Cr}(\mathrm{VI})$ toxicity. Several apoptotic response genes, including those involved in the p53 signaling pathway such as OKL38 [51], transcription factor E2F1 [52], and Gadd45a [53], were overexpressed in the $\mathrm{Cr}(\mathrm{VI})$-treated fibroblasts suggesting the possible involvement of mechanisms dependent on p53, an important stress-responsive and apoptotic regulatory gene [54], in $\mathrm{Cr}(\mathrm{VI})$-induced apoptosis and cytotoxicity in the cells.

Because of the widespread presence of chromium as a contaminant in various consumer products and in cement and the ability of chromium to cause dermal toxicity, especially ACD, some investigators have suggested restricting the amount of $\mathrm{Cr}(\mathrm{VI})$ present in consumer products, such as detergents, to $<5 \mathrm{ppm}$ [55]. Addition of reducing agents, for example $\mathrm{FeSO}_{4}$, to facilitate the reduction of water-soluble and toxic $\mathrm{Cr}(\mathrm{VI})$ to insoluble and, therefore, less permeable trivalent chromium has been suggested as a feasible approach to prevent or at least to reduce the toxicity of $\mathrm{Cr}(\mathrm{VI})$ that is present as a contaminant in various industrial and consumer products. For example, a significant reduction in the incidence of $\mathrm{ACD}$ has been observed among construction workers in certain European countries where the addition of $\mathrm{FeSO}_{4}$ to cement has been mandated [56]. However, in spite of the limited epidemiological evidence demonstrating the beneficial effect of $\mathrm{FeSO}_{4}$ to prevent the toxicity and illnesses resulting from exposure to $\mathrm{Cr}(\mathrm{VI})$, the addition of $\mathrm{FeSO}_{4}$ to products that contain $\mathrm{Cr}(\mathrm{VI})$ is not universally accepted or practiced in several countries, including the US. One of the reasons for this might be the lack of adequate experimental data to support the protective role of $\mathrm{FeSO}_{4}$ in the $\mathrm{Cr}(\mathrm{VI})$-induced 
Citation: Sellamuthu R, Umbright C, Chapman R, Leonard S, Li S, et al. (2011) Transcriptomics Evaluation of Hexavalent Chromium Toxicity in Human Dermal Fibroblasts. J Carcinogene Mutagene 2:116. doi:10.4172/2157-2518.1000116

Page 7 of 8

toxicity. Currently, by employing human dermal fibroblasts as an in vitro experimental model for human skin, we have obtained data to demonstrate the potential protective role of $\mathrm{FeSO}_{4}$ in the apoptosis, oxidative stress, differential gene expression, and cytotoxicity induced by hexavalent chromium. The present findings warrant additional animal and epidemiological studies to confirm the protective role of $\mathrm{FeSO}_{4}$ in $\mathrm{Cr}(\mathrm{VI})$-induced dermal toxicity for potential application in cases of human exposure to $\mathrm{Cr}(\mathrm{VI})$ and the resulting toxicity and illnesses.

\section{References}

1. Joseph $\mathrm{P}, \mathrm{He} Q$, Umbright $\mathrm{C}$ (2008) Heme-oxygenase 1 gene expression is a marker for hexavalent chromium-induced stress and toxicity in human dermal fibroblasts. Toxicol Sci 103: 325-334.

2. Zhitkovich $A$ (2005) Importance of chromium-DNA adducts in mutagenicity and toxicity of chromium(VI). Chem Res Toxicol 18: 3-11.

3. Bagchi D, Bagchi M, Stohs SJ (2001) Chromium (VI)-induced oxidative stress, apoptotic cell death and modulation of p53 tumor suppressor gene. Mol Cell Biochem 222: 149-158.

4. Briggs JA, Briggs RC (1989) The in vitro transformation of a rat liver epithelial cell line with chromium. Biol Trace Elem Res 21: 431-435.

5. Kim HY, Lee SB, Jang BS (2004) Subchronic inhalation toxicity of soluble hexavalent chromium trioxide in rats. Arch Toxicol 78: 363-368.

6. Zhou Y, Vaidya VS, Brown RP, Zhang J, Rosenzweig BA, et al. (2008) Comparison of kidney injury molecule-1 and other nephrotoxicity biomarkers in urine and kidney following acute exposure to gentamicin, mercury, and chromium. Toxicol Sci 101: 159-170.

7. Shelnutt, SR, Goad P, Belsito DV (2007) Dermatological toxicity of hexavalent chromium. Crit Rev Toxicol 37: 375-387.

8. Subramanian S, Rajendiran G, Sekhar P, Gowri C, Govindarajulu P, et al (2006) Reproductive toxicity of chromium in adult bonnet monkeys (Macaca radiata Geoffrey). Reversible oxidative stress in the semen. Toxicol Appl Pharmacol 215:237-249.

9. Athavale P, Shum KW, Chen Y, Agius R, Cherry N, et al. (2007) Occupational dermatitis related to chromium and cobalt: experience of dermatologists (EPIDERM) and occupational physicians (OPRA) in the U.K. over an 11-year period (1993-2004). Br J Dermatol 157: 518-522.

10. IARC (1990) Chromium, nickel and welding. IARC Monographs on the Evaluation of Carcinogenic Risks to Humans, Vol. 49. IARC Scientific Publications, IARC, Lyon, France.

11. Costa M, Klein CB (2006) Toxicity and carcinogenicity of chromium compounds in humans. Crit Rev Toxicol 36: 155-163.

12. Goon AT, Goh CL (2005) Metal allergy in Singapore. Contact Dermatitis 52 : 130-132.

13. Turk K, Rietschel RL (1993) Effect of processing cement to concrete on hexavalent chromium levels. Contact Dermatitis 28: 209-211.

14. O'Brien TJ, Ceryak S, Patierno SR (2003) Complexities of chromium carcinogenesis: role of cellular response, repair and recovery mechanisms. Mutat Res 533: 3-36.

15. Fullerton A, Gammelgaard B, Avnstorp C, Menne T (1993) Chromium content in human skin after in vitro application of ordinary cement and ferrous-sulphatereduced cement. Contact Dermatitis 29: 133-137.

16. Gentleman RC, Carey VJ, Bates DM, Bolstad B, Dettling M, et al. (2004) Bioconductor: open software development for computational biology and bioinformatics. Genome Biol 5: R80.

17. Benjamini $Y$, Hochberg $Y$ (1995) Controlling the false discovery rate: a practical and powerful approach to multiple testing. J R Stat Soc Ser 57: 289-300.

18. Martin BD, Schoenhard JA, Hwang JM, Sugden KD (2006) Ascorbate is a prooxidant in chromium-treated human lung cells. Mutat Res 610: 74-84.

19. Quievryn G, Peterson E, Messer J, Zhitkovich A (2003) Genotoxicity and mutagenicity of chromium( $\mathrm{VI}) /$ ascorbate-generated DNA adducts in human and bacterial cells. Biochemistry 42: 1062-1070.

20. Mahadev K, Wu X, Zilbering A, Zhu L, Lawrence JT, et al. (2001) Hydrogen peroxide generated during cellular insulin stimulation is integral to activation of the distal insulin signaling cascade in 3T3-L1 adipocytes. J Biol Chem 276: 48662-48669.

21. Liu SX, Athar M, Lippai I, Waldren C, Hei TK (2001) Induction of oxyradicals by arsenic: implication for mechanism of genotoxicity. Proc Natl Acad Sci U S A 98: 1643-1648

22. Joseph P, Muchnok TK, Klishis ML, Roberts JR, Antonini JM, et al. (2001) Cadmium-induced cell transformation and tumorigenesis are associated with transcriptional activation of c-fos, c-jun, and c-myc proto-oncogenes: role of cellular calcium and reactive oxygen species. Toxicol Sci 61: 295-303.

23. Gavin IM, Gillis B, Arbieva Z, Prabhakar BS (2007) Identification of human cell responses to hexavalent chromium. Environ Mol Mutagen 48: 650-657.

24. Ye J, Shi X (2001) Gene expression profile in response to chromium-induced cell stress in A549 cells. Mol Cell Biochem 222: 189-197.

25. Mikalsen, A, Alexander J, Wallin $H$, Ingelman-Sundberg M, Andersen RA (1991) Reductive metabolism and protein binding of chromium(VI) by P450 protein enzymes. Carcinogenesis 12: 825-831.

26. Gunaratnam MM, Pohlscheidt M, Grant MH (2002) Pretreatment of rats with the inducing agents phenobarbitone and 3-methylcholanthrene ameliorates the toxicity of chromium (VI) in hepatocytes. Toxicol In Vitro 16: 509-516.

27. Liddell JR, Hoepken HH, Crack PJ, Robinson SR, Dringen R (2006) Glutathione peroxidase 1 and glutathione are required to protect mouse astrocytes from iron-mediated hydrogen peroxide toxicity. J Neurosci Res 84: 578-586.

28. Dringen R, Hamprecht B (1997) Involvement of glutathione peroxidase and catalase in the disposal of exogenous hydrogen peroxide by cultured astroglial cells. Brain Res 759: 67-75.

29. Ewing JF, Maines MD (1993) Glutathione depletion induces heme oxygenase-1 (HSP32) mRNA and protein in rat brain. J Neurochem 60: 1512-1519.

30. Gosslau A, Ruoff P, Mohsenzadeh S, Hobohm U, Rensing L (2001) Heat shock and oxidative stress-induced exposure of hydrophobic protein domains as common signal in the induction of hsp68. J Biol Chem 276: 1814-1821.

31. Baird SK, Kurz T, Brunk UT (2006) Metallothionein protects against oxidative stress-induced lysosomal destabilization. Biochem J 394: 275-283.

32. Schlittenhardt D, Schober A, Strelau J, Bonaterra GA, Schmiedt W, et al. (2004) Involvement of growth differentiation factor-15/macrophage inhibitory cytokine-1 (GDF-15/MIC-1) in oxLDL-induced apoptosis of human macrophages in vitro and in arteriosclerotic lesions. Cell Tissue Res 318: 325-333.

33. Chan K, Han XD, Kan YW (2001) An important function of Nrf2 in combating oxidative stress: detoxification of acetaminophen. Proc Natl Acad Sci U S A 98: 4611-4616.

34. He X, Lin GX, Chen MG, Zhang JX, Ma Q (2007) Protection against chromium (VI)-induced oxidative stress and apoptosis by Nrf2. Recruiting Nrf2 into the nucleus and disrupting the nuclear Nrf2/Keap1 association. Toxicol Sci 98: 298309.

35. Kalayarasan S, Sriram N, Sureshkumar A, Sudhandiran G (2008) Chromium (VI)-induced oxidative stress and apoptosis is reduced by garlic and its derivative S-allylcysteine through the activation of Nrf2 in the hepatocytes of Wistar rats. J Appl Toxicol 28: 908-919.

36. Ishii T, Itoh K, Yamamoto M (2002) Roles of Nrf2 in activation of antioxidan enzyme genes via antioxidant responsive elements. Methods Enzymol 348 182-190.

37. Leonard SS, Vallyathan V, Castranova V, Shi X (2002) Generation of reactive oxygen species in the enzymatic reduction of $\mathrm{PbCrO} 4$ and related DNA damage. Mol Cell Biochem 234-235: 309-315.

38. Ye J, Wang S, Leonard SS, Sun Y, Butterworth L, et al. (1999) Role of reactive oxygen species and p53 in chromium(VI)-induced apoptosis. J Biol Chem 274 34974-34980.

39. Zhan Q (2005) Gadd45a, a p53- and BRCA1-regulated stress protein, in cellular response to DNA damage. Mutat Res 569: 133-143.

40. Smith ML, Chen IT, Zhan Q, Bae I, Chen CY, et al. (1994) Interaction of the p53-regulated protein Gadd45 with proliferating cell nuclear antigen. Science 266: $1376-1380$

41. Villunger A, Michalak EM, Coultas L, Mullauer F, Bock G, et al. (2003) p53- and drug-induced apoptotic responses mediated by $\mathrm{BH} 3$-only proteins puma and noxa. Science 302: 1036-1038 
Citation: Sellamuthu R, Umbright C, Chapman R, Leonard S, Li S, et al. (2011) Transcriptomics Evaluation of Hexavalent Chromium Toxicity in Human Dermal Fibroblasts. J Carcinogene Mutagene 2:116. doi:10.4172/2157-2518.1000116

42. Yamochi T, Kaneita Y, Akiyama T, Mori S, Moriyama M (1999) Adenovirusmediated high expression of BCL-6 in CV-1 cells induces apoptotic cell death accompanied by down-regulation of BCL-2 and BCL-X(L). Oncogene 18: 487494

43. Okamura S, Arakawa H, Tanaka T, Nakanishi H, Ng CC, et al. (2001) p53DINP1, a p53-inducible gene, regulates p53-dependent apoptosis. Mol Cell 8: 85-94.

44. Kokkinakis DM, Brickner AG, Kirkwood JM, Liu X, Goldwasser JE, et al. (2006) Mitotic arrest, apoptosis, and sensitization to chemotherapy of melanomas by methionine deprivation stress. Mol Cancer Res 4: 575-589.

45. Kubli DA, Quinsay MN, Huang C, Lee Y, Gustafsson AB (2008) Bnip3 functions as a mitochondrial sensor of oxidative stress during myocardial ischemia and reperfusion. Am J Physiol Heart Circ Physiol 295: H2025-2031.

46. Roth W, Stenner-Liewen F, Pawlowski K, GodzikA, Reed JC (2002) Identification and characterization of DEDD2, a death effector domain-containing protein. J Biol Chem 277: 7501-7508.

47. Foskett SM, Ghose R, Tang DN, Lewis DE, Rice AP (2001) Antiapoptotic function of Cdk9 (TAK/P-TEFb) in U937 promonocytic cells. J Virol 75: 12201228.

48. Weinreb O, Amit T, Bar-Am O, Chillag-Talmor O, Youdim MB (2005) Novel neuroprotective mechanism of action of rasagiline is associated with its propargyl moiety: interaction of Bcl-2 family members with PKC pathway. Ann N Y Acad Sci 1053: 348-355.
49. Segura MF, Sole C, Pascual M, Moubarak RS, Perez-Garcia MJ, et al. (2007) The long form of Fas apoptotic inhibitory molecule is expressed specifically in neurons and protects them against death receptor-triggered apoptosis. J Neurosci 27: 11228-11241.

50. Basu P, Morris PE, Haar JL, Wani MA, Lingrel JB, et al. (2005) KLF2 is essentia for primitive erythropoiesis and regulates the human and murine embryonic beta-like globin genes in vivo. Blood 106: 2566-2571.

51. Yao H, Li P, Venters BJ, Zheng S, Thompson PR, et al. (2008) Histone Arg modifications and p53 regulate the expression of OKL38, a mediator of apoptosis. J Biol Chem 283: 20060-20068.

52. Blattner C, Sparks, A, Lane D (1999) Transcription factor E2F-1 is upregulated in response to DNA damage in a manner analogous to that of p53. Mol Cell Biol 19: 3704-3713.

53. Liebermann DA, Hoffman B (2008) Gadd45 in stress signaling. J Mol Signa 3: 15 .

54. Johnstone RW, Ruefli AA, Lowe SW (2002) Apoptosis: a link between cancer genetics and chemotherapy. Cell 108: 153-164.

55. Basketter DA, Briatico-Vangosa G, Kaestner W, Lally C, Bontinck WJ (1993) Nickel, cobalt and chromium in consumer products: a role in allergic contact dermatitis? Contact Dermatitis 28: 15-25.

56. Avnstorp C (1989) Prevalence of cement eczema in Denmark before and since addition of ferrous sulfate to Danish cement. Acta Derm Venereol 69: 151-155. 